\title{
THE ROLE OF DALIHAN NA TOLU IN ENHANCING THE TOURISM APPEAL OF PARBABA WHITE SAND BEACH IN SAMOSIR REGENCY AS INDONESIA'S NATIONAL GEOPARK
}

\author{
Rosnidar SEMBIRING* \\ University Sumatera Utara, Faculty of Law, Department of Civil Law, University Street No.4, \\ Padang Bulan, Medan Baru, Medan, Sumatera Utara 20155, e-mail: rosnidar@usu.ac.id

\section{Erna HERLINDA} \\ University Sumatera Utara, Faculty of Law, Department of Civil Law, University Street No.4, \\ Padang Bulan, Medan Baru, Medan City, Sumatera Utara 20155, e-mail: erna@usu.ac.id
}

\section{Afrita AFRITA}

University Sumatera Utara, Faculty of Law, Department of Civil Law, University Street No.4, Padang Bulan, Medan Baru, Medan, Sumatera Utara 20155, e-mail: afita@usu.ac.id

\section{Suria NINGSIH}

University Sumatera Utara, Faculty of Law, Department of Civil Law, University Street No.4, Padang Bulan, Medan Baru, Medan, Sumatera Utara 20155, e-mail: suria@usu.ac.id

\section{Iskandar MUDA}

University Sumatera Utara, Faculty Economic and Business, Department of Accounting, Street Prof. TM Hanafiah 12, Padang Bulan, Medan, Indonesia, 20155, e-mail: iskandar1@usu.ac.id

Citation: Sembiring, R., Herlinda, E., Afrita, Ningsih, S., \& Muda, I. (2019). THE ROLE OF DALIHAN NA TOLU IN ENHANCING THE TOURISM APPEAL OF PARBABA WHITE SAND BEACH IN SAMOSIR REGENCY AS INDONESIA'S NATIONAL GEOPARK. GeoJournal of Tourism and Geosites, 26(3), 701-713. https://doi.org/10.30892/gtg.26302-390

\begin{abstract}
The purpose of this study is to analyze some factors that influence the inhibition of local communities in the development of tourism in the White Sand of Parbaba, Indonesia. The type of research is an empirical juridical method. It was conducted in Huta Bolon Village, Pangururan Subdistrict, Samosir Regency, North Sumatera Province, Indonesia. The research sample was collected using the technique of Stratified Random Sampling. The findings of this research, it can be concluded that the community of Huta Bolon Village, Pangururan Subdistrict, Samosir Regency still lack tourism awareness. This is evidenced by the findings in which garbage scatters along the beach, and poultry and cattle roam around the beach.
\end{abstract}

Key words: Dalihan Natolu, tourism, local communities, Parbaba white sand beach, Indonesian National Geopark

\footnotetext{
* Corresponding author
} 


\section{INTRODUCTION}

In Indonesia, tourism is one of the sectors that play an important role in the sustainability of Indonesian economy. If managed well and properly, tourism development as one of the industries will create prosperity through advances in transportation, accommodation, and communications that create relatively large employment opportunities. Based on the Regulation of North Sumatera Governor No. 34 of 2015 concerning the Agency for Management of the Geopark of Toba Caldera of North Sumatera Province (Republic of Indonesia, 2016), The Samosir Regency is designated as Indonesia's National Geopark. This is consistent with the Research Master Plan of the University of North Sumatera (RIP) Years 2016 to 2020 in the legal, social, and cultural sectors, namely development of research into the potential of the community's culture and community participation to support the harmony of the environment. This is further described in the strategic program on social life of the community, namely social life, politics, economy, culture, and religion of the community, views, and cultural exploration, preservation, utilization, prospect, and development. Pursuant to the Regulation of North Sumatera Governor No. 34 of 2015 concerning the Agency for Management of the Geopark of Toba Caldera of North Sumatera Province (Republic of Indonesia, 2016), The Samosir Regency has been designated as Indonesia's National Geopark. Furthermore, it is stipulated in the strategic program on social life of the community, namely social life, politics, economy, culture, and religion of the community, views, and cultural exploration, preservation, utilization, prospect, and development. Samosir is an area with promising potential for tourism, such as nature attractions (Lake Aek Natonang and Lake Sidihoni), hot springs, Lake Toba, waterfalls, and historic attractions associated with the Batak peoples such as Sopo Tatea Bulan, Aek Sipitu Dai (water with seven flavours), Marhosa Stone, Hobon Stone, and Guru Stone. Dilemmas arise when the philosophy of the Batak peoples, namely Dalihan NaTolu (hulahula, dongan tubu, and anak boru) is applied to tourists. Tourists are considered new comers and serve as boru who have provide services, while the Batak peoples (locals are called hula-hula) should be treated like a king. However, in the concept of tourism, the opposite applies where it is tourists (both local and foreign one) who are to be served.

Geopark is an area that has geological elements in which local communities are invited to play a role in protecting and improving the function of natural heritage (Mossa et al., 2018), including the archeological, ecological and cultural values contained within it. In 2000, European Union (EU) countries began implementing the Manifesto on Earth Heritage and Geodiversity (Ruban, and Yashalova, 2018). They placed geomorphology as the main component of the landscape. Du and Girault (2018) state this effort is supported by many international organizations such as the European Geopark Network, the International Association of Geomorphology (IAG), the International Union of Geological Sciences (IUGS), and the International Geographical Union (IGU). In the Asia-Pacific region, a similar Geopark network was formed, which remains affiliated with UNESCO (Mossa et al., 2018). The establishment of the Asia-Pacific Geopark Network was initiated by countries that already have Global Geopark namely China, Japan, Malaysia and Australia. The main purpose of Geopark is to protect the geological heritage that is in European countries by a non-governmental organization called EGN (Europe Geopark Network) in 2001 (Nikolova \& Sinnyovsky, 2019). The existence of Geopark by the World Agency (United Nations Educational, Scientific and Cultural Organization/UNESCO) was developed and facilitated by forming the GGN (Global Geopark Network) organization in 2004 to be able to accommodate more members from countries in the world. In addition, the purpose of Geopark is further developed, not just protecting geological heritage. 
According to the UNESCO GGN (2004), the purpose of Geopark is to take advantage, explore, appreciate and develop the geological heritage. Samosir is an area with promising potential for tourism, such as nature attractions (Lake Aek Natonang and Lake Sidihoni), hot springs, Lake Toba, waterfalls, and historic attractions associated with the Batak peoples such as Sopo Tatea Bulan, Aek Sipitu Dai (water with seven flavours), Marhosa Stone, Hobon Stone, and Guru Stone. Any tourist attractions which are created by God and constitute ancestral heritage are extremely priceless treasures because they will continuously generate income for the region if managed well. Directly, it can be seen that the community of Samosir still lack the awareness of the existence of extremely valuable treasures around them. Among the evidence suggesting such a condition is that despite the plan to make Lake Toba as the World's geopark and tourism in Samosir as the Monaco of Asia, garbage still scatters around the road to the tourist attraction and quality of the services provided to tourists remains poor. Considering the facts, based on the research into the community of Samosir, it is necessary to improve their human resources in order to improve service quality and quality of tourism in Samosir Regency (Pardede and Purnama, 2016). The tourist destination of the lake Parbaba White Sand Beach is located in Huta Bolon Village, Pangururan Subdistrict, Samosir Regency. The geographical location is in Figure 1 below. Based on the Figure 1 shows that the location of Parbaba White Sand Beach from the capital of the Province of North Sumatra plated 5 hours 55 minutes.

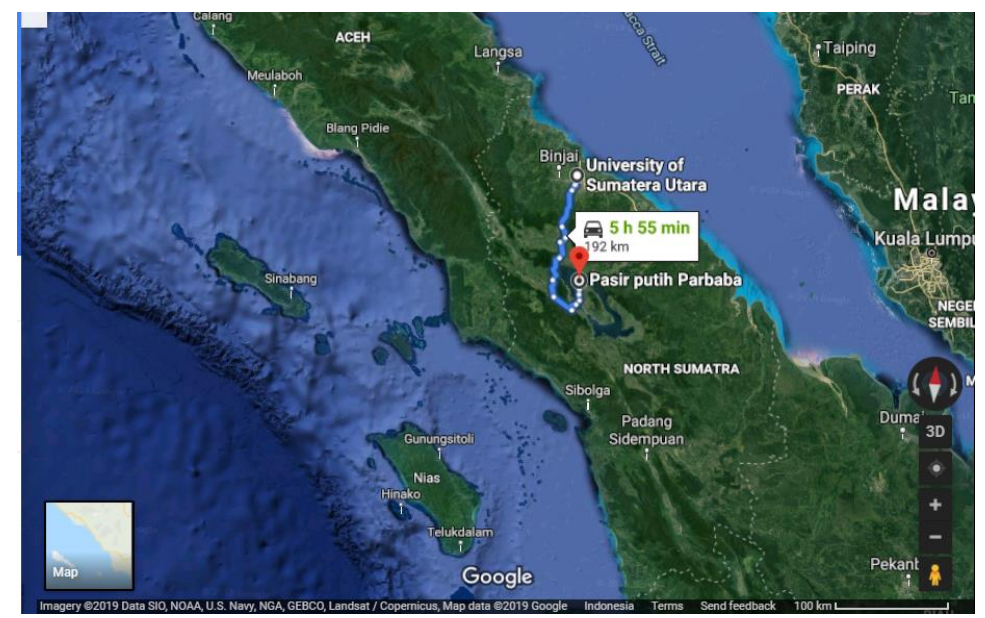

Figure 1. The geographical location of Parbaba White Sand Beach (Source: Google Maps 2018)

While the geographical location in Google Maps images is as follows in Figure 2.

It was the Government of Samosir Regency that suggested designating white sand beach areas as a tourist attraction in 2006 due to their natural potential to serve as a tourism area. The uniqueness of this tourist attraction lies in its white sand. The Batak Toba peoples which are the native inhabitants of Huta Bolon Village, Pangururan Subdistrict, Samosir Regency have a philosophy, which serves both as a principle as well as a structure and a system in its society, known as Dalihan Na Tolu. Dalihan Na Tolu, i.e. a philosophy or a socio-cultural insight relating to the Batak peoples and their culture. Dalihan $\mathrm{Na}$ Tolu serves as a framework which includes relations by blood and by marriage which connect one group. Dalihan $\mathrm{Na}$ Tolu as the kinship system of the Batak peoples has an equally important value with the system which is very popular nowadays, namely democracy. Dalihan Na Tolu symbolizes the way of life of the Batak peoples amid 
the community. The kinship system of the Batak peoples puts one in 3 (there) exact positions since birth to death known as Dalihan Na Tolu. Dalihan Na Tolu is a cultural system of the Batak Toba peoples. The value it contains is adopted as the way of life and serves as a source of motivation which guides their behaviour (Nainggolan, 2010).

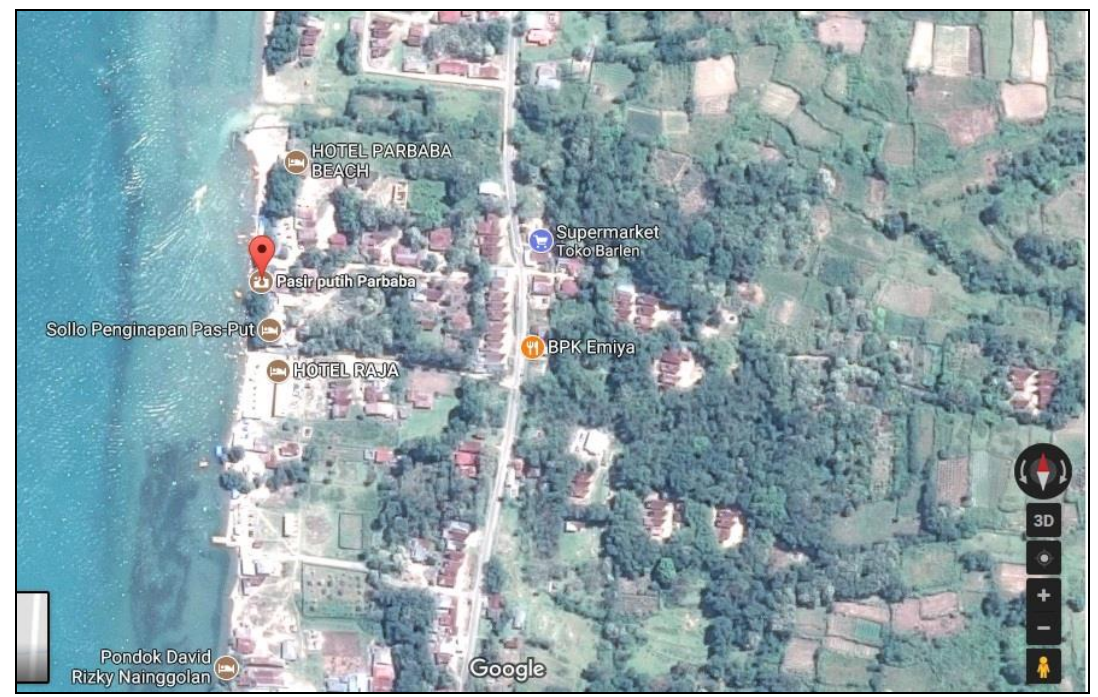

Figure 2. The geographical location of Parbaba White Sand Beach with google maps (Source: Google Maps 2018)

Once one becomes the Batak Toba peoples, she/he must be ready to have dual social status, as a "king", a "fellow", and a "servant". In the customary law terms, these are referred to as "hula-hula" (king), "dongan tubu" (fellow), and "boru" (servant). These three terms are known as the Dalihan $\mathrm{Na}$ Tolu triangle. If implemented amid the community of a "huta" (village), then the "marga (name of the clan) of the king" who opens, controls, and governs the "huta" will automatically become "the King of the Huta" and "hula-hula" and at the same time will have the status as "suhut ni huta" (the Host). Then, the other margas whose wife has the same marga as „the king's marga „will automatically become "boru" (guest clan). "Dongan tubu" is a relative of the same marga in and outside the village. The triangular relationship between "hula-hula", "dongan tubu", and "boru" is guided by the following norms: "Somba marhula-hula; manat mardongan-tubu; elek marboru." which can be interpreted as "respect for "hula-hula"; solidarity for „dongan tubu", love for "boru”. Of the three statuses, the status of "hulahula" and "boru" is the most prominent one for the Batak peoples. "Hula-hula" is the "king”, while "boru” is a "servant". "Somba" (worship, respect) to "hula-hula" is the task of "boru", and "elek" (persuasion, love) to "boru" is "hula-hula". Dilemmas arise when these are applied to tourists. In the context of the social structure of "huta", tourists are outsiders and thus they fall into the category of "guest marga" or "boru", while the Batak peoples are "the King of Huta", "the king's marga" aka "suhut" or the host. The problem is that in the theory and practice of tourism, tourists are "the king who has to be served". In this matter, the Batak peoples who claim to be "the king of huta" ("hula-hula") in fact should serve tourists who are perceived as "guest marga" ("boru”). In addition, the habit of the Batak peoples who always litter, allow livestock to roam everywhere, and refuse transfer of land rights due to the belief that land belongs to the public, which is magisch 
komunalistik in nature (known as communal rights) serve as the factors inhibiting the advancement of tourism of Parbaba White Sand Beach in Huta Bolon Village, Pangururan Subdistrict, Samosir Regency which is included in the Indonesian National Geopark.

In essence, the participation of the community by showing their friendly attitude is expected to be the basis of the creation of global tourism in the international arena (Fandeli, 2010). Actually in their everyday life, the Batak peoples have already known the so-called Poda Na Lima which serves as a principle of morality taught for generations and taught since they are in elementary school in the Land of Batak. The role of Dalihan $\mathrm{Na}$ Tolu in reviving Poda Na Lima is a necessity for tourism development at Parbaba White Sand Beach located in Huta Bolon Village, Pangururan Subdistrict, Samosir Regency. Based on the foregoing, the following problems can be formulated (1) What factors from the local community inhibit development of Parbaba White Sand tourism? (2) What is the role of Dalihan Na Toluin enhancing the appeal of Parbaba White Sand tourism in Samosir Regency as Indonesia's National Geopark? And (3) What solutions are offered to the factors that inhibit development of Parbaba White Sand tourism?

\section{LITERATURE REVIEW}

\section{Geopark}

Geopark is a component related to nature and life on earth. The Geopark concept has three basic meanings (Nikolova \& Sinnyovsky, 2019), namely:

1. It is an area that has a meaning as a geological heritage so it needs to be preserved, as well as a place to apply a sustainable economic development strategy carried out through a good and realistic management structure. Geopark is an area that contains various types of geological elements that have meaning and function as natural heritage (Nikolova \& Sinnyovsky, 2019). In this area various strategies for sustainable regional development can be implemented, whose promotion must be supported by government programs. As a region, the Geopark must have clear and clear boundaries. The Geopark surface area must also be sufficient, meaning that it can support the implementation of its development action plan activities (Ruban \& Yashalova, 2018).

2. Implementing geopark provides an opportunity for job creation for local communities in terms of gaining real economic benefits through sustainable tourism activities. Geopark contains a number of geological sites (geosite) that have meaning from the side of science, scarcity, beauty (aesthetics), and education. Activities in Geopark are not limited to geological aspects, but also other aspects such as archeology, ecology, history and culture.

3. Geological heritage objects and geological knowledge shared with the general public. The existing geological and landscape elements are related to aspects of the natural and cultural environment. Park. The geological site of the Geopark is part of the earth's heritage. Based on the meaning, function and opportunity of its use, the existence and preservation of these sites need to be protected and protected.

\section{Indonesia's National Geopark}

Geopark is a management concept of sustainable tourism development that combines three natural varieties, namely geology and geomorphology (Geodiversity), Geoheritage geodiversity, and Geodiversity conservation (Geoconservation). Indonesia currently has five areas that have been declared a national park by the Geological Agency of the Ministry of Energy and Mineral Resources Ministry of the Creative Economy. The five areas are Mount Sewu (covering three provinces, Central Java, Yogyakarta, and East Java); Merangin (Jambi); Mount Rinjani (West Nusa Tenggara); Lake Toba (North Sumatra); and Mount Batur (Bali). Especially for Mount Batur has been declared by the 
United Nations Educational, Scientific and Cultural Organization (UNESCO) in 2012 as one of the world's international Geopark (Perdana, 2013).

\section{Sustainable Tourism}

Building sustainable tourism is not just about controlling and managing the negative impacts of the industry. But it puts the sector in a privileged position to provide economic and social benefits to local communities, and to raise awareness and support for environmental conservation. In the tourism sector, economic development and environmental protection should not be seen as opposing forces, but must be interconnected with each other as aspirations that can and should be mutually reinforcing (UNEP-UNWTO 2005). For that purpose UNWTO (2004) states that sustainable tourism should: 1) optimally utilize environmental resources that are a key element in tourism development; 2) respecting the socio-cultural authenticity of local communities; and 3) ensuring a viable long-term economic impact, by providing socioeconomic benefits to all stakeholders, including stable employment and social services for local communities, and contributing to poverty alleviation.

A key challenge in sustainable tourism is developing economically viable enterprises that provide livelihood benefits to local communities while protecting indigenous cultures and environments (Simpson, 2007 and Tomori, 2010). Sustainable tourism development requires the participation of information from all stakeholders, as well as strong political leadership to ensure broad participation and build consensus (Strba, 2015). Achieving sustainable tourism is an ongoing process and requires constant monitoring of impacts, introducing necessary preventive and/or remedial measures when needed. Sustainable tourism should also maintain the level of tourism satisfaction and ensure a meaningful experience for tourists, raise their awareness on sustainability issues and promote environmentally friendly tourism practices among them (Egresi \& Polat, 2016 and Carvache et al., 2018). UNEP-UNWTO (2005) states that sustainability is the responsibility of all parties involved in tourism. However, there is a clear need for governments to take a leading role. This is due to: 1) The tourism industry is highly fragmented; 2) Sustainability relates to areas of public concern; and 3) Governments have many tools that can be used to make a difference-such as the power to legislate and offer economic incentives, and resources and institutions to promote and disseminate good practice. To that end, the Government should provide space and encourage the private sector, tourists and other stakeholders to respond to sustainability issues (Chakrabarty \& Mandal, 2018). This can be achieved by establishing and implementing a series of policies for the development and management of sustainable tourism. To ensure the long-term sustainability of the tourism sector, there is a need for effective policies and plans at all levels, especially at the local level, where tourism activities take place. Where travellers interact with service providers and communities, and where the most positive and negative tourism impacts (UNWTO \& MMTE 2007).

\section{Sustainable Tourism Development Policy}

Allan et al. (2015) state that the development of tourism products and tourism activities in an area can be detailed consisting of (1) selected attractions developed that have high selling value of natural attractions, heritage, culture and artificial objects, (2) infrastructure (facilities, utilities) constructed according to local culture and traditions and integrated with their environment, (3) local institutions are strengthened and given greater role, (4) human resources is the determinant of tourism success in accordance with its target, (5) economic aspect developed is populist economy. Earnings of the area intended to be able to maintain or conserve the area and improve the welfare of local communities, (6) the environment of tourism areas should be assessed feasibility, especially positive impacts and negative impacts that will arise. Environmental Impact 
Analysis is an instrument for assessing environmental impacts and how to deal with them (Fandeli \& Nurdin, 2005; Coratza et al., 2015).

In the development of sustainable tourism development policy, many methods have been used. Lu \& Nepal (2009) in his paper entitled Sustainable tourism research, has analyzed and identified research papers published in the Journal of Sustainable Tourism, which is the only international journal which exclusively presents research on sustainable tourism. In this paper it is stated that most papers (139 or 41\%) have applied qualitative methods, followed by quantitative methods (125 or 37\%) and mixes (21 or 6\%), while $16 \%$ are theoretical papers. The data collection methods used in the analysis of sustainable destinations remains unchanged, with social survey methods and case studies as the two most commonly applied methods. In this article it is also emphasized that the concept of sustainable tourism can only be carried out efficiently if there are sustainability indicators that are useful, reliable and understandable. In line with the results of the study (Lu \& Nepal 2009), UNEP-UNWTO (2005) states that defining and using sustainability indicators is a key component in the process of planning and managing sustainable tourism. Given these indicators, it is possible to monitor changes over time in a constant and consistent manner. Indicators can be used to indicate: 1) current state of the industry; 2) pressure on the system; 3) the impact of tourism; 4) management efforts; and 5) the impact of management actions. Indicators provide early warning of when a new policy or action change may be needed, and also provides the basis for long-term planning and review of tourism. It is further explained that an indicator can be measured by complementary alternatives and methods (the use of different instruments) and can be described in different forms, both quantitative and qualitative (UNWTO 2004).

\section{RESEARCH METHODS}

This is empirical juridical research. Juridical research is a descriptive research, a research model that seeks to create a picture/exposure and dig carefully and deeply about certain social phenomena without intervening and hypothesis. The purpose of descriptive research is to clarify the picture systematically, accurately about the facts under investigation. Based on this, the techniques of data collection used include direct observation, through the interview, as well as in-depth interviews, Focus Group Discussion (FGD) and their study data documentation in the form of government policies relating to tourism. The main research approach used is qualitative approach, so the main data is qualitative. However, to complete the analysis of qualitative data, it will be displayed and reinforced also with data that is quantitative, with the understanding that this study using qualitative paradigms equipped and reinforced with quantitative data. Qualitative analysis used is descriptive inductive, while quantitative data used is percentage in tabulation form. So in accordance with the purpose of research, then for qualitative data presented in the form of inductive description. The research was undertaken in Huta Bolon Village, Pangururan Subdistrict, Samosir Regency, North Sumatra Province. Among the tourist destinations in the area of Lake Toba is Parbaba White Sand Beach is located in Huta Bolon Village.

The research population consisted of the community of Huta Bolon Village residing in the research site. The number of respondents coming from the community was determined using the technique of stratified random sampling based on their livelihood and age. The data from the selected community were obtained using questionnaires and afterwards, in-depth interviews with several informants such as Head of Huta Bolon Village, Subdistrict Head, Customary Leaders (FKTM), Tourism Office of Samosir Regency, and Office of Culture, Youth, and Sport of Samosir Regency. 


\section{RESULT AND DISCUSSION \\ Result}

\section{General Description of the Research Site}

Samosir Regency is regency which formerly was part of Toba Samosir Regency in accordance with the Law No. 36 of 2003 dated 18 December 2003 concerning Establishment of Samosir and Serdang Bedagai Regencies. The establishment of Samosir as a new regency is the first step to start accelerated development towards a more prosperous society. Pangururan is one of the subdistricts in Samosir Regency and is the capital of Samosir Regency, North Sumatera. Pangururan consists of several villages such as Huta Bolon, Parbaba, Sialanguan, Sinabulan, Lumbansuhi, and so on. As the capital of the Regency, Pangururan has several tourist attractions that are visited by many tourists, including Parbaba White Sand Beach, Hot Spring, Museum of the Inculturated Catholic Church, Boru Naibaho Tree Area, Huta Bolon Volly Beach, Tano Ponggo Bridge, and Indah Situngkir Beach. Huta Bolon Village is one of the villages in Pangururan Subdistrict, Samosir Regency. This village was selected as the research site after Lake Toba has been designated as Toba Caldera Geopark based on Regulation of North Sumatera Governor No. 34 of 2015. One of the tourist destinations in Lake Toba is Parbaba White Sand Beach located in Huta Bolon Village. Almost all of the residents inhabiting this village come from the same clan, namely Batak Toba, and are either Protestants or Catholics and uphold the philosophy of "Dalihan Natolu" where customs are maintained and preserved in various aspects of life. Thus, any major conflicts among society almost never occur, except for minor conflicts among individuals. The inhabitants of Huta Bolon Village also have long adopted the system of gotong royong (mutual assistance) which has been handed down from generation to generation in their everyday life such as in wedding ceremony, death ceremony, ceremony to celebrate a new house, and so on. The community of Huta Bolon Village always participate in the implementation of such events either in terms of money and other tangible objects or energy.

Factors from the Local Community that Inhibit Development of Parbaba White Sand Tourism.

In this research, the team of researchers conducted observation to the research site and interviewed the community relating to the topic of the research. Based on the interviews, it was revealed that among the factors from the local community that inhibit development of Parbaba White Sand Tourism is that the community remain lacking tourism awareness as shown by garbage which still scattered everywhere. The Chief of Huta Bolon Village, Belly Boiking Sihaloho adds that even though garbage collectors and garbage containers have been hired, they often work to collect the garbage the next day after they receive a call (the schedule to collect garbage is every two weeks).As for the issue of livestock, which still wandered everywhere, in fact a regional regulation stipulating the obligation to put livestock in a cage and/or watch them, namely the Regional Regulation No. 26 of 2006 (Republic of Indonesia, 2006), but the community do not comply with it saying that the Civil Service Police Unit (Satpol PP) almost never carried out their task inspecting the area, there is no village regulation stipulating livestock, and there are no firm sanctions against such violation. Based on interviews with the community of Huta Bolon Village, it is revealed that the presence of tourists in Parbaba White Sand Beach causes them a number of troubles, especially teenage tourists as their behaviour can be detrimental to morals of the village residents such as: displaying affection in front of the public or wearing clothes considered less polite to wear, which the village residents believe that such things will damage their cultural order. Moreover, the guests who visited that place often threw shards of glass into the lake. 
The Role of Dalihan Na Tolu in Enhancing the Tourism Appeal

of Parbaba White Sand Beach in Samosir Regency as Indonesia's National Geopark

\section{The Role of Dalihan Na Tolu in Enhancing the Appeal of Parbaba White Sand Tourism}

Dalihan Na Tolu which is often called "Tungku Nan Tiga" is an expression which expresses kinship in the clan Batak. Meanwhile, according to the Dictionary of Batak Toba Culture, Dalihan Na Tolu is defined as the basis of community life for all Batak peoples, which consists of three elements or frameworks, each constitutes an integral part (Marbun \& Hutapea, 1987). Dalihan Na Tolu is the basic cultural concept of the Batak peoples that is very unique. Literally, Dalihan Na Tolu means kaki tongue Nan tiga and is a symbol for the social system of the Batak peoples consisting of three pillars, namely dongan sabutuha, boru, and hula-hula. This is consistent with a motto of the Batak peoples, namely manat mardongan tubu, elek marboru, somba marhula-hula, which means: "You should be careful with the friends of the same marga, serve boru, and show the attitude of worshipping towards hula-hula" (Siahaan, 1982). The customary group Dalihan $\mathrm{Na}$ Tolu is found in all the Batak peoples, although they may use different terms, but the meaning is the same. In the Batak Toba peoples, it is called Dalihan Na Tolu, which consists of the following elements: Dongan Sabutuha, Hula-Hula, and Boru. In the Mandailing community, this is also called Dalihan $\mathrm{Na}$ Tolu, which consists of the following elements: Kahanggi, i.e. family of the same marga or family by blood; Mora, i.e. family of the wife (who give the wife); and Boru, i.e. family that take the wife or the family of the sonin-law. In the Batak Karo community, it is called Sangkep Si Telu, which consists of Kalimbubu, Senina, and Anak Beru. Then, in the Batak Simalungun community, this is called Tolu Sahundulan, which consists of Tondong, Senina, and Boru (Sihombing, 1986).

The term Dalihan Na Tolu comes from the words Dalihan which means Tungku and Na Tolu which means Nan Tiga. The elements of Dalihan Na Tolu, namely dongan sabutuha, hula-hula, and boru should be in agreement and incorporated in every activity held either to celebrate happiness such as marriage and in the face of distress or misfortune. The Batak peoples believe that prosperity and happiness will be realized if the three functional elements of Dalihan $\mathrm{Na}$ Tolu unite as in the human existence, which consists of three elements, namely hosa (breath), mudar (blood), and sibuk (the flesh) (Sinaga, 2000). Dongan Sabutuha, hula-hula, and boru, which constitute the elements of Dalihan $\mathrm{Na}$ Tolu, is an adapt institution or a consultative council that will determine everything relating to the group. Dalihan Na Tolu has mechanisms to resolve all conflicts that occur in the group by holding close-family meetings, adapt meetings, or community meetings. The elements of Dalihan Na Tolucan serve as mediators between the two conflicting parties, but if this mediation fails, then hula-hula may act as an arbitrator who resolves the conflict using his power by making a coercive decision (Sitanggang, 1986).

Dalihan Na Tolu is the main pillar that supports the life of the whole cultural order of the Batak peoples consisting of hula-hula - dongan sabutuha - boru. It is above the three furnace legs the whole socio-cultural order is based (Harahap, 1987). Dalihan Na Tolu constitutes a form of culture of the Batak peoples that stipulates kinship among individuals. Dalihan Na Tolucan is illustrated as a three-leg cooking furnace in the kitchen where pots are placed upon it consisting of the following elements: parties of the same marga, parties receiving a wife, and parties giving a wife. Dalihan $\mathrm{Na}$ Tolu is one of the main values of the core cultural values of the clan Batak (Daulay, 2006). Based on findings of field research according to the information from the informants, Dalihan Na Tolu will definitely play a role in enhancing the tourism appeal of Parbaba White Sand Beach, for example in terms of development of tourism infrastructure (Sinaga, 2017). Dalihan Na Tolu plays a positive role because in the development of this tourist attraction according to the customs and beliefs of the local community, only the marga that establishes the village (i.e. hula-hula) is entitled to 
undertake any construction-related activities in that area. However, as Dalihan Na Tolu adopts the principle of equality in term of positions ( 3 furnaces) in the genealogy of the family, the guest marga (anak boru) can also provide assistance in the development of the area. This is consistent with Naibaho (2017) stating that Dalihan Na Tolu is instrumental not only in the development of tourism but also in the issues of security among individuals. If one of the elements of Dalihan $\mathrm{Na}$ Tolu disappears, life will not run well. The three principles in Dalihan Na Tolu include: 11) Sombah Marhula-hula, which means showing respect to hula-hula, if one shows respect to his/her guest by treating the guest like hulahula, he/she will be respected as well; 2) Manat Mardongan Tubu, which means showing tolerance to family of the same merge; 3) Elek Marboru, which means showing empathy or affection to anak boru. Nevertheless, Dalihan Na Tolu can also inhibit tourism as stated by Sihaloho (2017) saying that in the event that Dalihan Na Tolu provides real contribution, this will inhibit tourism because the principle of tourism states that guests or newcomers, in this case tourists, are considered as hula-hula, while the host is considered as anak boru.

Conversely, the Parbaba community actually consider tourists as boru because they are newcomers while the local sare hula-hula because they are the ones who established the village. Anyone who comes must respect them as the host, not on the contrary in which it is those tourists who should be respected. In addition, characters of the Batak peoples are very different from those of people from Solo and Jogyakarta, for example if tourists ask a discount on the stuffs they sell, but finally do not buy them, they will get angry. Actually, Dalihan $\mathrm{Na}$ Tolu should play a role here, i.e. to change it, but the regional government in this case the Department of Culture and Tourism never gives any instruction on this issue.

One's position in Dalihan Na Tolu will also affect his/her everyday life. Someone who happens to have a position in the government but in Dalihan Na Tolu his/her position is as anak boru will feel hesitate to reprimand his/her hula-hulanya even though his/her hula-hulanya has made a mistake. In so doing, the implementation of the principle Dalihan Na Tolu can also hinder the development of tourism.

\section{Discussion}

\section{Solutions to the Factors that Inhibit Development of Parbaba White Sand Tourism}

In relation to the inhibiting factor from the locals, especially the condition where garbage scattered everywhere, there should be a Village Regulation stipulating that the village community should throw away their garbage to garbage cans, which applies for both organic and inorganic waste, and then it should also stipulate waste recycle, which later can be used for fertilizer, and garbage collectors must come every 2 days, rather than every 2 weeks to take the garbage to the landfill. This village regulation will also stipulate the so-called „garbage levy" that villagers must pay each month along with the sanctions given to those villagers who fail to comply with this Village Regulation. As for the issue of villagers' livestock that still roam everywhere, the Government of Samosir Regency the Tourism Office will directly meet the community to introduce and distribute information about the Regional Regulation No. 26 of 2006 concerning the obligation to put livestock in a cage and/or watch them. To individual business owners such as tents, hotels, boats, and so on, they are expected to control their own business well and pay the income tax to the Government of Samosir Regency, as so far they have not done it. Even the Chief of Huta Bolon Village adds that the owner of Hotel Raja in Parbaba White Sand Beach and owners of restaurants here, if they are invited to attend "Musrembang", they never come. Thus, it is hard to expect that they will pay the $10 \%$ tax on meals and levies on lodging (Sihaloho, 2017). Manurung (2017) states the Tourism Office of the Government of Samosir Regency states that in the last 3 years, tourism in Samosir Regency has made 
progress as can be seen in the increasing number of visitors every month and participation of the Government of Samosir Regency cq the Tourism Office, for example by:

1. Establishing tourism-aware groups (Pokdarwis).

2. Controlling the price set by providers of facilities such as hotels, restaurants (culinary), personal tents, boats, and so on.

3. Organizing events for 1 year.

4. Participating in the exhibition held in Jakarta, by joining brand travel (between sellers and buyers)

5. Conducting travel dialogue in Jakarta (Manurung, 2017).

According to Limbong (2017), the Office of Culture and Sport of Samosir Regency often hold art galleries although he claims that the dance "si lima peak" originated in this area, however presently they have to bring dancers from another region (Dairi) if they want to present the dance because it no longer exists in this area (not preserved) (Limbong, 2017). Japito Sinaga argues that the time has come for Dalihan Natolu to adopt the principle called Poda na lima in each occasion/ meeting such as in the traditional marriage ceremony, death ceremony, and so on, namely:

1. Paias rohamu (clean your heart)

2. Paias pamatangmu (clean your body)

3. Paias paheanmu (clean your clothes)

4. Paias bagasmu (clean your house)

5. Paias pakaranganmu (clean your yard) (Sinaga, 2017).

Subdistrict Chief Nainggolan later adds that literally the meaning can also be interpreted as follows: that we need to clean our soul, body, clothes worn/covering our body, house (family), and yard (the environment where we live).

Paisa Roam (clean your heart/soul) means no dirt found and can also mean the purity of the soul from envy (gut-gut), jealousy, and arrogance. Maintaining the cleanliness and purity of the soul is a good advice in order that we can always maintain a good relationship with God, others, and the environment (nature) rationally and proportionally in accordance with the needs of mankind today and at a later time. Characters such as envy, jealousy, and arrogance will ruin the cleanliness and purity of the human soul. On the contrary, sincerity, sportsmanship, and simplicity will bring humanity to their level of honour. Paisa Pamatangmu (clean your body) tells us to always maintain the cleanliness of our body physically and cleanliness of our behaviour from various evil deeds. To have a good body, people need a good intake and a good lifestyle as well. The word pamatang (body) here can be interpreted to include maintenance of the whole body as well as the five senses that encourage people to do good or evil deeds. By maintaining cleanliness of the body, people will be able to control the behaviour and politeness and avoid various damage resulting from their actions.

Paias Pamatangmu (clean your body) tells us to always maintain the cleanliness of the clothes both physically, i.e. clothes that cover aurat (parts of the body that should be covered by clothes so that they cannot be seen by the opposite sex) or clothes that means the symbols we wear accompanying our life such as marga (descendants), huta (village), customs, and so on. Paias Pamatangmu (clean your body) tells us to always maintain the cleanliness of the house itself and the house which is interpreted as bagas or the family (descendants). In the customs of the Batak peoples, the definition of bagas (house) is very broad as it is not only defined as a place to stay but can also is interpreted as sappopparan (the same ancestor/the same marga/family by blood) and everyone has the duty to protect and maintain family prestige and dignity. Bagas can also mean family. Paias Pakaranganmu (clear your yard) means we must always maintain the cleanliness 
of the environment where we live. In the narrow sense, a yard can mean the yard of the house or the environment where we live (huta). Usually, in one huta (village), especially in the land of the Batak peoples, most of the residents living in one village remain having close kinship. Generally, in one village there is always a family relationship that is often referred to as Dalihan $\mathrm{Na}$ Tolu, which the kinship system in the customs of the Batak peoples. A yard can also be interpreted as Dalihan Na Tolu, namely Sauhut (kahanggi), Anak Boru dohot Morana (hula-hula).It will be really wise if those advised from grandfathers/grandmothers (oppu) of the Batak peoples are implemented nowadays as some people no longer care about morality in their life.

\section{CONCLUSIONS AND SUGESTION}

The local community in this case the community of Huta Bolon Village, Pangururan Subdistrict, Samosir Regency remain lacking tourism awareness, as evidenced by the facts where garbage scattered everywhere and livestock roamed everywhere, despite the enactment of the Regional Regulation No. 26 concerning the obligation to put livestock in a cage and/or watch them. The role of Dalihan Natolu in enhancing the tourism appeal of Parbaba White Sand in Samosir Regency as a National Geopark on the one hand is instrumental in changing the behaviour of the local community by socializing Poda Na Lima (clean your soul, body, clothes, house, and yard) on each occasion such as in traditional marriage celebration, death ceremony, and so on, but on the other hand it is also considered inhibiting the development of tourism itself because it considers the local community as hula-hula and visitors/tourists or newcomers as boru whom should not be respected or served, contrary to the concept of tourism in which it is visitors whom they should serve as these visitors provide revenue to their village. In relation to the solutions to the development of Parbaba White Sand, it is necessary to establish a Regional/Village Regulation setting out types of organic and inorganic waste, temporary disposal site, final disposal site, and sanctions. The regional regulation concerning collection of taxes on hotels, restaurants, private tent owners, private board owners, parking fees, and the like should be stipulated in such a way that later those types of collection will be returned for the welfare of the local community so as to instil a view that they have to maintain the cleanliness of the beach for the sake of their own prosperity.

\section{REFERENCES}

Allan, M., Dowling, R. K., \& Sanders, D. (2015). The motivations for visiting geosites: the case of Crystal Cave, Western Australia. GeoJournal of Tourism and Geosites, 16(2): 141-152.

Carvache-Franco, M., Carvache-Franco, O., Carvache-Franco, W., Villagómez Buele, C., \& Arteaga Peñafiel, M. (2018). The Tourist Demand from The Perspective of The Motivation, Assessment and Satisfaction In A Sun And Beach Destination: The Manta Case, Ecuador. GeoJournal of Tourism and Geosites, 22(2): 561-572.

Chakrabarty, P., \& Mandal, R. (2018). Geotourism Mapping for Sustainability: A Basin Oriented Approach. GeoJournal of Tourism and Geosites, 21(1): 174-185.

Coratza, P., Ghinoi, A., Piacentini, D., \& Valdati, J. (2008). Management of geomorphosites in high tourist vocation area: an example of Geo-hiking maps in the Alpe di Fanes (Natural Park of Fanes-Senes-Braies, Italian Dolomites). Geojournal of tourism and geosites, 2(2): 106-117.

Daulay, A.S, (2006). Indigenous Batak Culture Dalihan Na Tolu: Analysis from the Angle of Principles and Their Importance in Integrating Integration and National Identity, http://marbun.blogspot.com/ 2006/11/dalihan-na-tolupenjelasan.html. (Accessed on 16.07.2017).

Daulay, A.S, (2006). Indigenous Cultural Batak Dalihan Na Tolu: Analysis From The Corner of Principles and Its Urgency in Knitting Integration and Identity of the Nation. http://marbun.blogspot.com/2006/11/ dalihan-na-tolupenjelasan.html. (Accessed on 16.07.2017).

Du, Y., \& Girault, Y. (2018). A Genealogy of UNESCO Global Geopark: Emergence and Evolution. International Journal of Geoheritage and Parks, 6(2): 1-17. 
The Role of Dalihan Na Tolu in Enhancing the Tourism Appeal of Parbaba White Sand Beach in Samosir Regency as Indonesia's National Geopark

Egresi, I., \& Polat, D. (2016). Assessing tourists' satisfaction with their shopping experience in Istanbul. GeoJournal of Tourism and Geosites, 9(2): 172-186.

Fandeli, C. (2010). Understanding and Basic Concept of Ecotourism. Faculty of Forestry Universitas Gadjah Mada Press. Yogyakarta.

Fandeli, C., \& Nurdin, M. (2005). Conservation-Based Ecotourism Development in the Park. UGM Publishers. Yogyakarta.

Harahap, S. (1987). Orientation of Values of Batak Culture, Willem Iskandar Studio, Publishers. Jakarta.

Kolosinska, M., Petrashchak, O., Kolosinskyi, I., \& Katana, A. (2018). Tourism Sector in Transition Economy On Example of Ukraine: Determinants of Competitiveness. GeoJournal of Tourism and Geosites, 21(1): 239-252.

Limbong, P. (2017). The Office of Culture and Sport of Samosir Regency. Working Paper. Medan.

Lu, J. \& Nepal, S.K., (2009). Sustainable tourism research: an analysis.Journal of Sustainable Tourism, 17(1): 5-16.

Manurung, P.N.J.H. (2017). Head of the Office of Tourism of the Government of Samosir Regency, Working Paper. Medan.

Marbun, M.A. \& Hutapea, I.M.T (1987). Batak Cultural Dictionary Toba, Balai Pustaka Publishers. Jakarta.

Marbun, M.A. \& Hutapea, I.M.T. (1987). Toba Batak Cultural Dictionary, Balai Pustaka Publishers. Jakarta.

Mossa, A., Camúñez-Ruiz, J. A., \& Morandi, F. (2018). Current State of The First UNESCO Global Geopark: A Case Study of The Geological And Mining Park Of Sardinia, Italy. GeoJournal of Tourism and Geosites. 22(2): 403-418.

Naibaho, O. (2017). Vice Chief of FKTM of Samosir Regency Chapter. Working Paper. Medan.

Nainggolan, S.R. (2010). The Existence of Indigenous Cultural Batak Dalihan Na Tolu in Batak Society (Case Study of Batak Perantau Society in Brebes Regency). Journal of Philosophy. 18(2): 8-19.

Nikolova, V., \& Sinnyovsky, D. (2019). Geoparks in the legal framework of the EU countries. Tourism Management Perspectives, 29(1): 141-147.

Pardede, F. \& Purnama, R.E. (2016). Management Strategy of Samosir Regency as Nature Tourism Attraction in North Sumatera Province. Tourism Destinations Journal. 4(1): 5-15.

Perdana, P.P. (2013). Related statements about the quality of Human Resources. http://properti.kompas. $\mathrm{com} / \mathrm{read} / 2013 / 12 / 13 / 2121222 /$ Indonesia.Kini.Punya.Lima.Taman.Bumi (Accessed on 16.07.2017).

Ruban, D.îA., \& Yashalova, N.N. (2018). Geodiversity meanings in global geoparks: an empirical study. Environmental Earth Sciences, 77(22): 771-785.

Siahaan, N, (1982). Dalihan Na Tolu Adat: Principles and Implementation. Grafina Publishers. Jakarta.

Sihaloho, B.B. (2017). Chief of Huta Bolon Village. Working Paper. Medan.

Sihaloho. L, (2017). Resident of Huta Bolon Village. Working Paper. Medan.

Sihombing, T.M, (1986). Batak Philosophy on Customary Habits, Balai Pustaka Publishers. Jakarta.

Simpson, M.C., (2007). An integrated approach to assess the impacts of tourism on community development and sustainable livelihoods. Community Development Journal, 44(2): 186-208.

Sinaga, J. (2017). Member of FKTM of Nainggolan Subdistrict Chapter, Working Paper. Medan.

Sinaga, J. (2017). Secretary of the Chief of Palipi Subdistrict, Working Paper. Medan.

Sinaga, R. (2000). Indigenous Cultural Batak and Christianity. Main Dian Publishers. Jakarta.

Siregar, Junita. (2017). Chief of Nainggolan Subdistrict, Working Paper. Medan.

Sitanggang, H. (1986). Impact of Modernization on North Sumatra's Family Relationship, Depdikbud Project Inventory and Documentation of Regional Culture. Jakarta.

Sitanggang, H. (1986). The Impact of Modernization on Regional Relationship of North Sumatra, Depdikbud Project Inventory and Documentation of Regional Culture. Jakarta.

Štrba, L. (2015). Identification and evaluation of geosites along existing tourist trail as a primary step of geotourism development: Case study from the Spiš region (Slovakia). GeoJournal of tourism and geosites, 16(2): 126-140.

Tomori, M. (2010). Investigating shopping tourism along the borders of Hungary: A theoretical perspective. GeoJournal of Tourism and Geosites, 6(2): 202-210.

*** Republic of Indonesia (2003). Law Number 36 Year 2003, Establishment of Samosir Regency and Serdang Bedagai Regency in North Sumatra Province. Jakarta.

*** Republic of Indonesia (2006). Regulation No. 26 of 2006 abaout Regional regulation stipulating the obligation Regional. Jakarta.

*** Republic of Indonesia (2016). Regulation of North Sumatera Governor No. 34 of 2015 about Toba Caldera Geopark. Medan.

*** UNEP-UNWTO, (2005). Making tourism more sustainable. A guide for policy makers, URL: http://scholar.google.com/scholar?hl=en\&btnG=Search\&q=intitle:Making+Tourism+More+Sustainabl e:+A+Guide+for+Policy+Makers\#o. (Accessed on 16.07.2017).

*** UNWTO, (2004). Indicators of Sustainable Development for Tourism Destinations. URL: http://scholar.google.com/scholar?hl=en\&btnG=Search\&q=intitle:Making+Tourism+More+Sustainabl e:+A+Guide+for+Policy+Makers\#o. (Accessed on 16.07.2017).

Submitted:

26.11.2018
Revised:

16.07.2019
Accepted and published online 02.08.2019 